\title{
Distribusi Pendapatan dan Kekayaan dalam Ekonomi Islam
}

\author{
Ummi Kalsum \\ Fakultas Ekonomi dan Bisnis Islam IAIN Kendari \\ Email: kalsumummi75@gmail.com
}

\begin{abstract}
This article presents the critical study about distribution of income and wealth in Islamic economics perspective and 1945 constitution. The method of this study used descriptiveanalytical with library research approach. The result of this study showed that distribution of income and wealth is urgent in create the Human Falah. The main principles in distribution are justice and affection (brotherhood), meanwhile only there are two system of distribution, those are commercial with market mechanism and sistem which emphasize dimensions of justice for the weak people. In specifically doctrine of nationalism economy and doctrine of populist economy are present in article 33, 34, and 27, 1945 constitution of Indonesia. These articles are be the stronghold of nationalism economy and the stronghold for the prioritization of life neccesities whole of Indonesian people.
\end{abstract}

Keywords: income distribution, wealth distribution, Islamic economy.

\begin{abstract}
Abstrak
Artikel ini bertujuan untuk mengkaji secara kritis tentang distribusi pendapatan dan kekayaan dalam perspektif ekonomi Islam dan UUD 1945. Metode yang digunakan adalah deskriptif-analitis dengan pendekatan library research. Hasil studi menunjukkan bahwa distribusi pendapatan dan kekayaan sangat urgen dalam menciptakan human falah. Prinsip utama dalam distribusi adalah keadilan (justice) dan kasih sayang (persaudaraan) sementara sistem distribusi hanya dua, yaitu bersifat komersial melalui mekanisme pasar dan sistem yang menekankan dimensi keadilan yang diperuntukkan bagi kalangan yang lemah. Secara spesifik doktrin ekonomi kebangsaan dan doktrin ekonomi kerakyatan terdapat pada pasal 33, 34 dan 27 UUD 1945. Pasal-pasal ini menjadi benteng nasionalisme ekonomi dan benteng pengutamaan kepentingan kehidupan seluruh rakyat Indonesia.
\end{abstract}

Kata Kunci: distribusi pendapatan, distribusi kekayaan, ekonomi Islam

\section{A. Pendahuluan}

Kesenjangan perekonomian yang

terjadi di tanah air sudah sangat memprihatinkan dan merupakan fenomena umum. Hal ini bisa dilihat di sekeliling kita dan dari pemberitaan media massa maupun dari media elektronik. Faktor penyebab terjadinya hal tersebut adalah karena adanya ketidakadilan dan ketidakseimbangan dalam distribusi pendapatan dan kekayaan. Sebab ketidakseimbangan distribusi pendapatan merupakan sumber konflik individu maupun sosial (Nasition; 2007, 120). Afzalur Rahman (Rahman; 1985, 92) menambahkan 
bahwa kemiskinan yang diderita oleh masyarakat tidak sepenuhnya tergantung pada hasil produksi, tetapi juga tergantung pada distribusi pendapatan yang tepat. Sebab jika distribusi kekayaan tidak tepat maka sebagian besar kekayaan akan masuk ke kantong para kapitalis, sehingga akibatnya banyak masyarakat yang menderita kemiskinan dan kelebihan kekayaan negara tidak mereka nikmati.

Jika suatu negara mempunyai kelebihan kekayaan, tetapi distribusinya tidak berdasarkan pada prinsip keadilan dan kebenaran, maka negara itu belum dianggap berhasil. Begitu juga dengan kehidupan masyarakat modern yang mempunyai kekayaan yang melimpah namun di sisi lain masyarakat sekitarnya masih banyak yang menderita kemiskinan. Ini membuktikan bahwa distribusi pendapatan dan kekayaan yang belum merata.

Islam memberikan solusi untuk meminimalkan kesenjangan yang terjadi antara yang miskin dan yang kaya dengan cara distribusi pendapatan dan kekayaan yang merata. Sejalan dengan fokus teori distribusi pendapatan agar dapat mengatasi distribusi pendapatan nasional di antara berbagai kelas rakyat jelata, terutama menjelaskan fenomena semakin melebarnya jurang pemisah antara rakyat yang miskin dan kaya. Sebab titik berat dalam pemecahan problem ekonomi adalah bagaimana menciptakan mekanisme distribusi ekonomi yang adil dan merata di tengah masyarakat. Menanggapi kenyataan tersebut Islam sebagai agama rahmatan lil al-amin diharapkan dapat menyelesaikan permasalahan tersebut.

\section{B. Pengertian dan Prinsip Distribusi Pendapatan dan Kekayaan \\ Distribusi pendapatan} merupakan proses peredaran atau penyaluran harta dari yang empunya kepada pihak yang berhak menerimanya baik melalui proses distribusi secara komersial maupun melalui proses yang menekankan pada aspek keadilan sosial. Tujuannya adalah untuk memenuhi kebutuhan hidup tiap individu muslim maupun untuk meningkatkan kesejahteraannya, human falah. Pengertian ini berangkat dari prinsip bahwa kebutuhan dasar setiap individu harus terpenuhi dan pada kekayaan seseorang itu terdapat hak orang miskin, "Dan pada harta-harta mereka ada hak untuk orang miskin yang meminta dan orang miskin yang tidak mendapat bagian (tidak meminta)". (Q.s. al-Dzariyat [5l]: 19) 
Distribusi pendapatan dan kekayaan dalam ekonomi Islam berkaitan erat dengan nilai moral Islam, sebagai alat untuk mencapai kesejahteraan di dunia dan akhirat (falah). Untuk itu merupakan kewajiban kita sebagai hamba Allah agar memprioritaskan dan menjadikan distribusi pendapatan dan kekayaan yang bertujuan pada pemerataan menjadi sangat urgen dalam perekonomian Islam, karena diharapkan setiap manusia dapat menjalankan kewajibannya sebagai hamba Allah tanpa harus dihalangi oleh hambatan yang ada di luar kemampuannya. Oleh karena itu negara bertanggung jawab terhadap mekanisme distribusi dengan mengedepankan kepentingan umum dari pada kepentingan kelompok atau golongan. Sektor publik yang digunakan untuk kemaslahatan umat jangan sampai jatuh ke tangan orang yang mempunyai visi kepentingan kelompok atau golongan dan pribadi. Negara juga harus memastikan terpenuhinya kebutuhan minimal seluruh rakyatnya. (Q.s. al-Ruum: 38-39). A. Syafi'i Ma'arif sebagaimana dikutip oleh Sri-Edi Swasono- menegaskan bahwa tegaknya keadilan secara lebih merata sehingga kesenjangan sosial ekonomi yang sedang mengancam masa depan kita dapat diperkecil tidak menganga lebar seperti sekarang ini. Lebih lanjut beliau menambahkan pemimpinlah yang harus bisa membalik piramida tersebut, jika sosok semacam ini tidak bisa lahir dari rahim bangsa ini, maka kesimpulan sementara, kita telah gagal sebagai bangsa dan Negara (Swasono; 2010, 9899). Sebab standar kehidupan yang rendah menjadi penghalang bagi kemajuan suatu umat sehingga dibutuhkan solusi yang harus diselesaikan umat secara keseluruhan.

Prinsip utama yang menentukan dalam distribusi kekayaan adalah keadilan (justice) (Pusat Pengkajian \& Pengembangan Ekonomi Islam ; 2008, 59) dan kasih sayang (Rahman; 1995, 82). Keadilan distributif didefinisikan sebagai suatu distribusi pendapatan dan kekayaan yang tinggi, sesuai dengan norma-norma fairness yang diterima secara universal. Keadilan (Swasono; 2005, 2-3) dalam distribusi adalah penilaian yang tepat terhadap faktorfaktor produksi dan kebijakan harga, hasilnya sesuai dengan takar dan yang wajar serta ukuran yang tepat atau kadar yang sebenarnya. Keadilan juga berarti kebijaksanaan mengalokasikan sejumlah hasil tertentu dari kegiatan ekonomi bagi mereka yang tidak mampu memasuki pasar atau tidak sanggup 
membelinya menurut kekuatan pasar, yakni kebijakan melalui zakat, infak dan sedekah (Muhammad; 2005, 81). Hadis Nabi Saw: "Saya bersumpah kepada Allah; bukanlah orang beriman yang sepanjang hari makan kenyang sedang mereka mengetahui tetangganya dalam kelaparan". Ayat-ayat dan hadis di atas menunjukkan bahwa distribusi pendapatan dan kekayaan harus merata bagi seluruh umat manusia sesuai dengan kemampuan fisik, mental, pengetahuan dan keterampilan dalam melakukan kegiatan ekonomi. Implikasi pandangan ini adalah adanya persaudaraan universal, yang kemudian menimbulkan persamaan sosial dan menjadikan sumber daya alam sebagai amanah karena statusnya sebagai wakil Tuhan yang menciptakan alam semesta. Chapra menegaskan, persaudaraan akan hampa jika tidak diperkuat oleh keadilan dalam alokasi resources yang telah diberikan oleh Allah Swt (Chapra; 2001, 56-57). Prinsip ini tidak menghendaki adanya pemusatan harta dan penghasilan pada segelintir orang saja, dan untuk memperbaiki kemiskinan absolut serta mengurangi kesenjangan pendapatan dan kekayaan (Thurow; 2001, 238). Dengan bingkai kasih sayang akan terjalin persaudaraan (ukhwah) yang erat sehingga apapun yang terjadi bagi saudaranya maka yang lainnya ikut merasakannya.

Sementara bagi Mannan distribusi sebagai basis fundamental bagi alokasi sumber daya. Penekanan distribusi kekayaan tergantung pada kepemilikan orang yang tidak seragam. Menurutnya keadilan mutlak mensyaratkan bahwa imbalan juga seharusnya berbeda, dan sebagian orang memiliki lebih banyak dari yang lain. Hal ini wajar asalkan keadilan ditegakkan dengan prinsip kesempatan yang sama bagi semua orang. Oleh karena itu, ketidakmerataan itu sah-sah saja dan keadilan mutlak itu menurutnya karena disebabkan sumbangan yang berbeda. Namun baginya jika ketimpangan imbalan dengan kemungkinan terciptanya ketidakmerataan yang amat dalam di dalam pendapatan dan kekayaan, ia menegaskan bahwa pandangannya tidak akan melahirkan sebentuk kelas kapitalis tertentu karena ia menekankan dalam Islamic man dan nilai-nilai petunjuk serta norma-norma Islam didukung oleh transfer dan kewajiban agama berupa zakat dan sedekah dan bahwa kebutuhan dasar harus dijamin dan tersedia bagi semua orang (Haneef; 2010, 26-28). 
Al-Qur'an dan al-Sunnah sangat menekankan keadilan dan persaudaraan dan menjadikannya menjadi tujuan pokok syariat. Sebab penegakan keadilan dan penghapusan semua bentuk ketidakadilan sangat ditekankan dalam al-Qur'an sebagai misi utama Rasulullah Saw (Kahf; 1995, 135). Sementara prinsip distribusi versi $\mathrm{M}$. Anas Zarqa yang dikutip oleh Euis Amalia (Amalia; 2009, 118-119) adalah: pertama, prinsip pemenuhan kebutuhan bagi semua makhluk. Ini sebagai wujud dari rasa keadilan sebagai esensi dari maqasid syariah yang melindungi hakhak asasi manusia. Menurut as-Syatibi (Syatibi; tt, 374) kebutuhan dasar (dharuriyat) ada lima: pemenuhan kebutuhan agama, akal, kekayaan, jiwa dan keturunan. Kenyataannya tidak semua masyarakat mampu memenuhi kebutuhan tersebut terutama di kalangan masyarakat miskin. Dalam konteks ini Ibnu Hazm mengingatkan bahwa kemiskinan selalu tumbuh dalam situasi tingkat konsumsi atau kebutuhan lebih tinggi dari pendapatan. Kesenjangan antara yang kaya dengan yang miskin dapat menambah kesulitan saat keadaan orang kaya mempengaruhi struktur administrasi, cita-cita dan berbagai pengaruh lain seperti kenaikan harga dalam aktivitas ekonomi. Sehingga kesenjangan ekonomi akan semakin melebar antara si kaya dengan si miskin dan akan berdampak negatif terhadap kehidupan masyarakat, yang pada gilirannya akan mengganggu kehidupan masyarakat dan dapat mengganggu stabilitas keamanan dan stabilitas nasional.

Kedua, menimbulkan efek positif bagi pemberi itu sendiri misalnya zakat, selain dapat membersihkan diri dan harta muzakki juga meningkatkan keimanan dan menumbuhkan kebiasaan berbagi dengan orang lain, (Q.s. alTaubah [9]: 103-104). Ketiga, menciptakan kebaikan di antara semua orang antara yang kaya dan miskin. Keempat, mengurangi kesenjangan pendapatan dan kekayaan. Kelima, pemanfaatan lebih baik terhadap sumber daya alam dan asset tetap. Keenam, memberikan harapan pada orang lain melalui pemberian.

\section{Sistem dan Tujuan Distribusi Pendapatan dan Kekayaan \\ Sistem ekonomi kapitalis (al-ra'su} maliyah) (Chapra; 1999, 18) mengakui adanya kepemilikan individu, setiap individu dapat secara bebas mengumpulkan dan menghasilkan 
kekayaan dengan kemampuan yang dimiliki serta tidak ada batasan untuk memanfaatkan dan membagi harta yang dimilikinya, freedom of ownership kecuali hanya dibatasi oleh kepemilikan orang lain. Jangkauan properti privat setiap individu hanya dibatasi oleh kebebasan kepemilikan individu lain. Individu mendapat justifikasi atas kepemilikannya sekadar berdasarkan fakta bahwa dirinya manusia dan tidak mengganggu kebebasan orang lain. Kelompok ini melepaskan pemikirannya dari kerangka nilai atau norma-norma sehingga menimbulkan ketidakadilan distribusi pendapatan dan kecemburuan sosial. Perilaku ekonomi dengan tidak mempertimbangkan moral akan melahirkan tindakan monopoli (ihtikar), penimbunan (iktinaz), penarikan bunga dan lainnya yang dapat menyebabkan ketidakadilan distribusi pendapatan (tauzi' al-dakhl) (Ghafar; 1985, 408). Asas distribusi yang diterapkan oleh sistem kapitalis ini pada akhirnya berdampak pada realitas bahwa penguasa sebenarnya adalah para kapitalis (pemilik modal dan konglomerat). Oleh karena itu, hal yang wajar kalau kebijakan-kebijakan yang dikeluarkan oleh pemerintah selalu berpihak kepada pemilik modal atau konglomerat dan selalu mengorbankan kepentingan rakyat sehingga terjadilah ketimpangan (ketidakadilan) pendistribusian pendapatan dan kekayaan.

Berbeda dengan sistem ekonomi kapitalis, sistem ekonomi sosialis (alistirakiyah) tidak mengakui kepemilikan individu kecuali pada sektor-sektor tertentu seperti alat-alat yang sederhana dan tanah yang terbatas, begitu pula tidak ada pemindahan kekayaan melalui warisan dan investasi sehingga menyebabkan tidak terpenuhinya keadilan dalam distribusi pendapatan (Ghafar, 407). Oleh karena itu, pendapatan masyarakat menurut sistem sosialis ditentukan oleh negara disesuaikan dengan pendapatan negara dan ke mana pendapatan itu diinvestasikan ditentukan oleh kebijakan pemerintah tanpa memperhatikan kesejahteraan masyarakat. Dengan kata lain, distribusi pendapatan dalam sistem sosialis tidak memperhatikan skill dan etos kerja masyarakat serta sejauhmana kontribusi mereka dalam proses produksi. Kompetisi dalam sistem sosialis adalah hal yang tidak diperkenankan sehingga tentu saja dorongan untuk berprestasi dan meningkatkan produktivitas kerja menurun. Akibatnya sistem sosialis 
tidak mampu mendorong pertumbuhan ekonomi dengan baik (Amalia, 104-105). Dengan dalih untuk mewujudkan rasa keadilan dan kebersamaan, hak individu atas harta harus dihapuskan dan semua wewenang dialihkan kepada negara sehingga pemerataan tidak dapat diwujudkan (Muhammad, 310). Ternyata kedua sistem ekonomi ini tidak dapat memberikan solusi yang adil dan merata dalam hal pendistribusian pendapatan dan kekayaan.

Sementara ekonomi Islam tidak memiliki ajaran yang dianut oleh kedua sistem tersebut. Islam membangun filosofi dan sistemnya berdasarkan asas keadilan dan kebebasan. Islam menghendaki agar harta benar-benar terdistribusi dengan adil dan merata: “....supaya harta itu tidak beredar di antara orang-orang kaya saja di antara kamu.....(Q.s. al-Hasyr [59 ]: 7). Ayat tersebut menegaskan bahwa harta harus beredar di masyarakat tidak boleh ditumpuk dan dikuasai oleh sekelompok orang, ....dan orang-orang yang menyimpan emas dan perak dan tidak menafkahkannya pada jalan Allah, Maka beritahukanlah kepada mereka, (bahwa mereka akan mendapat) siksa yang pedih (Q.s. at-Taubah: 34). Harta harus berfungsi sosial sehingga dapat dinikmati oleh semua masyarakat dengan tetap mengakui hak kepemilikan dan melarang monopoli sebab harta berfungsi sosial. Di samping itu menumpuk harta dapat melemahkan daya beli masyarakat dan menghambat mekanisme pasar bekerja dengan adil.

Semua orang mempunyai hak yang sama, tidak ada diskriminasi dan secara umum, Islam mengarahkan kegiatan ekonomi berbasis pada akhlak al-karimah dengan mewujudkan kebebasan dan keadilan dalam aktivitas ekonomi. Keadilan dalam distribusi dan upaya dalam meminimalisir kesenjangan sosial, dalam ekonomi Islam ada dua sistem distribusi utama, yaitu: distribusi secara komersial dan melalui mekanisme pasar serta sistem distribusi yang mengedepankan pada aspek keadilan social (Antonio; 2009, 119). Sebab Sadr mengidentifikasi ada tiga kelas ekonomi di masyarakat, yaitu: pertama mereka yang memiliki mental dan atau kekuatan fisik untuk menghasilkan lebih kebutuhan mereka; kedua, orang-orang yang mampu bekerja tapi hanya sebatas memenuhi kebutuhan mereka; dan ketiga, mereka yang tidak memiliki kekuatan mental atau fisik untuk bekerja secara produktif. 
1. Sistem distribusi yang bersifat komersial (melalui mekanisme pasar).

Bagi kalangan yang mempunyai kekuatan ekonomi atau daya beli memenuhi kebutuhan hidup mereka dengan sistem distribusi yang bersifat komersial, yaitu lewat mekanisme pasar atau proses ekonomi biasa.

Adapun dalil keabsahan mekanisme ini berdasarkan Q.s. al-Nisa [4]: 29:
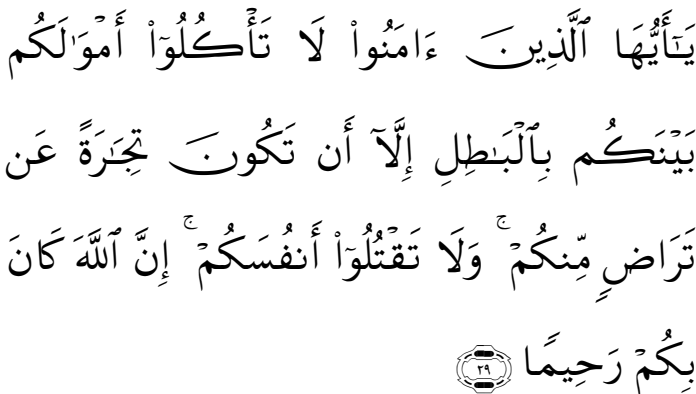

Artinya: Hai orang-orang yang beriman, janganlah kalian saling memakan harta sesame kalian dengan jalan yang batil kecuali dengan jalan perniagaan yang berlaku dengan suka sama suka di antara kalian. Dan janganlah kamu membunuh dirimu, sesungguhnya Allah adalah Maha Penyanyang kepadamu. (Q.s. al-Nisa [4]: 29)

Menurut Yusuf Qardawi dalam bukunya Daur al-Qiyam wa al-Akhlak fi alIqtishadi al-Islami yang dikutip oleh Amalia (Amalia, 119) bahwa ada empat aspek keadilan distribusi melalui proses ekonomi ini, yaitu: Pertama, gaji yang setara (al-ujrah al-mitsl) bagi para pekerja. Dalam distribusi pendapatan melalui pola hubungan perburuhan ini pekerja diposisikan sebagai mitra sehingga ia berhak atas upah atau gaji. Diriwayatkan oleh Abdullah ibn Umar bahwa Rasulullah Saw bersabda, yang artinya "Berikanlah upah orang upahan sebelum kering keringatnya" (al-Qazwayni, 817). Kedua, profit atau keuntungan untuk pihak yang menjalankan usaha atau yang melakukan perdagangan melalui mekanisme mudharabah maupun bagi hasil (profit sharing) untuk modal dana melalui mekanisme musyarakah. Dalil distribusi pendapatan melalui pola kemitraan usaha ini, diantaranya Q.s. Shad: 24 dan Q.s. al-Muzammil: 20. Ketiga, biaya sewa tanah serta alat produksi lainnya; Keempat, tanggung jawab pemerintah terkait dengan peraturan dan kebijakannya.

2. Distribusi dengan sistem yang berdimensi sosial.

Keadilan distribusi membutuhkan satu kondisi yang dapat menjamin terciptanya kesempatan yang sama pada setiap individu sebab di samping distribusi pendapatan dan kekayaan yang dilakukan dengan aktivitas ekonomi yang wajar dalam transaksi jual-beli dalam Islam diakui 
juga, sistem yang berdimensi sosial, yaitu Islam menciptakannya untuk memastikan keseimbangan pendapatan di masyarakat. Mengingat tidak semua orang mampu terlibat dalam proses ekonomi karena yatim piatu atau jompo dan cacat tubuh, Islam memastikan distribusi bagi mereka dalam bentuk zakat, infak, dan sedekah yang bersifat tidak mengikat sebagai alat distribusi. Zakat merupakan tindakan diri sosial yang merupakan kewajiban moral dari kelompok kaya untuk mendukung mereka yang miskin dan yang tidak beruntung di mana mereka tidak mampu membantu dirinya sendiri. (Q.s.: alHasyr [59]: 7:

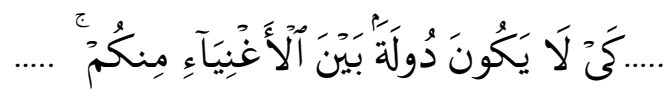

Artinya: “......Supaya harta itu jangan beredar di antara orang-orang yang kaya saja di antara kamu......".

Ayat ini menegaskan tentang pentingnya keadilan dalam distributif, karena keadilan merupakan isu sentral yang paling asasi dalam Islam. Secara tegas ayat ini menolak terkonsentrasinya kekayaan hanya pada segelintir orang. Secara implisit agar distribusi atau peredaran kekayaan lebih merata. Harta benda harus beredar di masyarakat sehingga dapat dinikmati oleh publik dengan tetap mengakui hak kepemilikan individu dan melarang monopoli karena dalam Islam harta berfungsi sosial.

Jika dianalisis manfaat distribusi pendapatan yang menekankan aspek keadilan ini bukan hanya sekedar tanggung jawab agar terpenuhinya kebutuhan para fakir dan miskin serta bukan hanya agar harta itu beredar tetapi ada nilai filosofis yang terkandung di dalamnya. Ibadah maliyah seperti ini (zakat, infak dan sedekah) dijanjikan Allah dalam Q.s. al-Baqarah [2]: 245 dan Q.s. al-Hadid [57]: 11 dengan balasan yang berlipat ganda, pada Q.s. alBaqarah [2]: 261. Balasan yang dijanjikan Allah tersebut tidak hanya dibalas di akhirat kelak tetapi di dunia juga. Dengan zakat, infak atau bersedekah harta akan berputar, dalam perspektif ekonomi semakin cepat perputaran uang maka semakin banyak kemungkinan keuntungan yang diperoleh. Kemudian coba kita hubungkan dengan teori sepotong roti al-Ghazali, dengan bersedekah sepotong roti saja sudah berapa banyak tenaga kerja yang terserap mulai dari tukang besi, tukang kayu, petani gandum, koki dan lain-lain (Othman; 2004, 23-25). Berarti dapat meningkatkan tingkat produktivitas karena si penerima, dengan bantuan 
yang ia terima akan mendorong terciptanya daya beli baru.

Di sisi lain jika seseorang bersedekah dengan ikhlas, ia akan merasakan kelezatan dan kenikmatan dalam membantu, dan gilirannya akan membawa ketenangan dan ketentraman jiwa bagi si pemberi yang dapat mendorongnya untuk lebih berkonsentrasi dalam usahanya (Shihab; 2008, 595). Sebab sedekah dapat menghilangkan sifat iri dan dengki dari orang yang tidak punya terhadap orang kaya sebab dengan bersedekah akan timbul ikatan emosional antara keduanya. Bahkan orang yang diberi akan melindungi si pemberi dari gangguan orang-orang yang tidak bertanggung jawab. Penerima sedekah, dengan bantuan yang diterimanya akan mampu mendorong terciptanya daya beli baru dan dapat meningkatkan produktivitas. Sekecil apapun sedekah yang diberikan akan memberikan kontribusi yang sangat signifikan dalam perekonomian

Dalam bersedekah tidak perlu ada kekhawatiran (Q.s. al-Baqarah [2]: 262) karena hartanya akan berkurang. Perlu dipahami bahwa harta tersebut tidak berkurang karena secara hakiki bahwa materi yang dikeluarkannya tetap miliknya tetapi ia hanya meminjamkannya kepada Allah. Jadi kekhawatiran harta berkurang tidak beralasan. Di samping itu sedekah adalah penolak bala.

Lebih lanjut ayat-ayat yang menerangkan distribusi yang menekankan aspek keadilan soaial adalah ayat-ayat tentang kewajiban membayar zakat, di antaranya: Q.s. alTaubah [9]: 60 yang menguraikan asnaf yang delapan orang yang berhak atau yang layak menerima zakat (muzakki), yaitu fakir miskin dalam berbagai variannya. Zakat merupakan suatu kewajiban setiap muslim untuk membayarkannya dari harta yang diakumulasikan, perdagangan, macammacam bisnis, pertanian, produksi dan ternak. Tujuannya adalah menciptakan dana untuk membantu secara ekonomi kepada golongan mustahiq. Di sisi lain, Negara juga harus proaktif untuk mengontrol dan mengambilnya dari wajib zakat (Q.s. al-Taubah [9]: 103) sebagaimana kebijakan yang dilakukan oleh khalifah Abu Bakar r.a. terhadap ketika orang-orang yang menolak untuk membayar zakat. Beliau memerangi mereka hingga mengeluarkan zakatnya.

Dalam landasan dasarnya, zakat bukan seperti pajak. Dana zakat tidak bisa disalurkan untuk pembangunan 
jalan, gedung dan lain-lain tetapi tujuannya hanyalah untuk memenuhi hak-hak orang yang telah ditentukan sebagaimana disebutkan pada Q.s. alTaubah [9]: 60 yang disebut dengan mustahiq.

Zakat akan bersinergi dengan kebijakan-kebijakan pemerintah dalam upaya untuk meningkatkan kesejahteraan masyarakat sekaligus untuk mengurangi angka kemiskinan di suatu negeri. Sebab tidak realistis mengharapkan pemerintah mengemban semua beban untuk mensejahterakan masyarakat. Bahkan jika dana zakat yang terkumpul tidak mencukupi para fuqaha memandang perlu tanggung jawab masyarakat muslim untuk mencari cara dalam mencapai tujuan. Efek positif zakat pada distribusi pendapatan dan kekayaan akan didorong lebih jauh oleh sistem pewarisan Islam (Chapra; 2001, 268).

Keindahan lain sistem redistribusi dalam Islam adalah warisan. Dengan warisan Islam ingin memastikan bahwa asset dan kekuatan ekonomi tidak boleh terpusat pada seseorang saja, betapa pun kayanya seseorang, jika si bapak meninggal maka anak, isteri, ibu, bapak, kakek, dan kerabat lainnya akan ke bagian peninggalannya. Untuk khalayak umum, Islam memperkenalkan instrumen distribusi lain, yaitu wakaf, yang berbentuk dan caranya bisa sangat banyak sekali, dari mulai gedung, uang tunai, buku, tanah dan asset-aset produktif lainnya. Berbeda dengan yang lainnya, wakaf tidak dibatasi oleh kaya atau miskin atau pertalian darah serta kekerabatan. Wakaf adalah fasilitas umum yang siapa pun boleh menikmatinya.

D. Kebijakan-kebijakan dalam Mendukung Pemerataan Distribusi Kekayaan

Kebijakan-kebijakan Islam dalam mewujudkan keadilan dalam distribusi pendapatan dan kekayaan adalah sebagai berikut:

1. Penghapusan Riba

Kata riba dalam bahasa Inggris diartikan dengan usury, yang berarti suku bunga yang lebih dari biasanya atau suku bunga yang mencekik. Sedangkan dalam bahasa Arab berarti tambahan atau kelebihan meskipun sedikit, atas jumlah pokok yang yang dipinjamkan.

Pengertian riba secara teknis menurut para fuqaha adalah pengambilan tambahan dari harta pokok atau modal secara batil baik dalam utang piutang maupun jual beli (al-Qurthubi; 1981, 128). Batil dalam hal ini merupakan 
perbuatan ketidakadilan (zalim) atau diam menerima ketidakadilan. Pengambilan tambahan secara batil akan menimbulkan kezaliman di antara para pelaku ekonomi. Dengan demikian esensi pelarangan riba adalah penghapusan ketidakadilan dan penegakan keadilan dalam perekonomian.

Secara luas penghapusan riba dapat dimaknai sebagai penghapusan segala bentuk praktik ekonomi yang menimbulkan kezaliman atau ketidakadilan. Riba jangan hanya dipahami dan direduksi pada masalah bunga bank saja. Tetapi secara luas riba bisa hidup laten atau poten di dalam sistem ekonomi yang diskriminatori, eksploitatori dan predatori yang berarti dapat hidup di dalam suatu sistem ekonomi subordinasi, kapitalistik, neoliberalistik dan hegemonik imperialistik, yang tidak bisa dibatasi dari segi perbankan saja (Swasono; 2008, 22-23). Karena itulah, pengembangan ekonomi syariah ke depan tidak dapat dilakukan secara isolasi atau parsial, tetapi harus dilakukan secara total. Dengan kata lain, ekonomi syariah tidak boleh direduksi hanya dengan memusatkan pada upaya membangun bank-bank syariah. Ekonomi syariah harus dapat menangkal sistem ekonomi yang exploitatory secara luas, yang memahami dan menumbuhkan kesenjangan ekonomi yang membiarkan terjadinya trade off secara sistemik untuk kerugian si miskin dan si lemah, yang tersubordinasi dan terdiskriminasi yang membiarkan berkembangnya laissez faire dalam arti luas tanpa memperhatikan perlunya dekonstruksi dan restrukturisasi sistem ekonomi yang usurious ini (Swasono; 2012, 24). Untuk itu dibutuhkan pakar ekonom muslim yang menguasai ilmu ekonomi konvensional sekaligus kontemporer sehingga mampu mengoreksi, mengimprovisasi dan lebih tangguh serta mumpuni mengantarkan ilmu ekonomi syariah ke arah tercapainya keadilan dan kemaslahatan umat di dunia dan di akhirat.

Pelarangan riba (prohibition of riba) dalam Islam secara tegas dinyatakan baik dalam Alquran maupun Hadis akan memperkuat lebih lanjut dampak reformasi moral.

Dalam perspektif ekonomi, pengharaman riba setidaknya disebabkan empat factor (Sadeq; 1989, 27-28), yaitu: pertama, sistem ekonomi ribawi menimbulkan ketidakadilan. Karena pemilik modal secara pasti akan dapat keuntungan tanpa 
mempertimbangkan hasil usaha yang dijalankan oleh peminjam. Jika peminjam dana tidak memperoleh keuntungan atau bangkrut usahanya, dia tetap membayar kembali modal yang dipinjamnya plus bunganya. Dalam kondisi seperti ini, peminjam sudah bangkrut ibarat sudah jatuh tertimpa tangga lagi dan tidak jarang penerapan bunga bukannya membantu usaha kreditor, justru menambah persoalan baginya. Di sinilah muncul ketidakadilannya.

Kedua, sistem ekonomi ribawi merupakan penyebab utama berlakunya ketidakseimbangan antara pemodal dengan peminjam. Keuntungan besar yang diperoleh para peminjam yang biasanya terdiri dari golongan industri raksasa (para konglomerat) hanya diharuskan membayar pinjaman modal plus bunganya dalam jumlah yang relatif kecil dibandingkan dengan keuntungan yang mereka peroleh. Sementara bagi penabung di bank-bank umum terdiri dari rakyat golongan menengah ke bawah tidak memperoleh keuntungan yang seimbang dari dana yang mereka simpan di bank.

Ketiga, sistem ekonomi ribawi akan menghambat investasi karena semakin tinggi tingkat bunga maka semakin kecil kecenderungan masyarakat untuk berinvestasi di sektor riil. Masyarakat lebih cenderung untuk menyimpan uangnya di bank karena keuntungan yang lebih besar disebabkan tingginya tingkat suku bunga.

Keempat, bunga dianggap sebagai tambahan biaya produksi. Biaya produksi yang tinggi akan menyebabkan naiknya harga barang-barang (produk). Naiknya tingkat harga, pada gilirannya akan mengundang terjadinya inflasi sebagai akibat lemahnya daya beli masyarakat.

Sementara dampak yang ditimbulkannya, diantaranya; pertama, akan menyebabkan krisis keuangan karena penerapan bunga sebagai indirect screening mechanism dalam sistem perekonomian gagal menjalankan fungsinya Siddiqi; 1997, 16-23). Kedua, terjadinya decoupling antara sektor riil dengan sektor moneter. Ini akan menyebabkan pasar barang akan lesu karena kurangnya suntikan dana dari pemilik modal sementara sektor moneter kebanjiran modal. Ketiga, terjadinya konglomerasi kekayaan dan kesenjangan ekonomi (Sakti; 2007, 237).

Jadi riba dapat mempengaruhi meningkatnya masalah dalam distribusi, yakni berhubungan dengan distribusi pendapatan antara bankir dan 
masyarakat secara umum, serta nasabah secara khusus dalam kaitannya dengan bunga bank.

\section{Zakat}

Zakat merupakan sedekah wajib yang berfungsi sebagai salah satu sistem distribusi pendapatan dan kekayaan yang menekankan aspek keadilan. Dengan zakat akan menjaga keseimbangan dan harmonisasi sosial antara orang kaya (muzakki) dan orang miskin (mustahik) seperti dijelaskan di atas. Selain itu dengan zakat, kebutuhan dasar tiap individu dalam Islam dijamin.

Zakat pada periode awal Islam dikelola oleh sebuah komite tetap dari pemerintahan dan menjadi bagian integral dari keuangan negara. Karenanya, kebijakan pengumpulan zakat maupun penyalurannya senantiasa terkait dengan kebijakan pembangunan Negara secara keseluruhan. Zakat tidak diberlakukan sebagai sebuah pos ritual semata, tetapi ia memiliki keterkaitan erat dengan kondisi riil masyarakat dalam satu Negara. Dengan pelembagaan seperti ini maka efektivitas maupun optimalitas pengelolaan zakat akan lebih terjamin (Pusat Pengkajian Ekonomi Islam UII; 2008, 71).
3. Pelarangan Gharar

Gharar dari segi bahasa dapat diartikan risiko atau ketidakpastian (uncertainty) (Indriyanto; 1980, 105). Padanan kata gharar, khada' yang berarti penipuan. Di samping itu gharar disamakan juga dengan kata khatara dengan makna sesuatu yang berbahaya. Sementara menurut Ibnu Taimiyah, gharar adalah sesuatu dengan karakter tidak diketahui sehingga menurutnya menjual hal ini adalah seperti perjudian. Ibnu Qayyim berpendapat gharar adalah sesuatu yang berkemungkinan ada atau tiada (Hulwati; 2006, 38).

Dengan demikian gharar merupakan transaksi dengan hasil (outcome) tidak dapat diketahui atau diprediksi. Ketidakpastian ini terjadi karena adanya kekurangan informasi oleh para pihak. Atau dengan kata lain, gharar adalah ketidakpastian terhadap barang yang diperdagangkan sehingga mengakibatkan penipuan. Misalnya, dalam hal jual beli dengan harga yang tidak ditentukan di muka, atau jual beli binatang yang masih berupa janin. Sabda Rasulullah Saw (Al-San'ani; 1379 H, 32): "Dari Ibn Mas'ud, dia berkata: bersabda Rasulullah Saw, janganlah kamu membeli ikan dalam air, karena ada unsur gharar". Larangan menjual ikan dalam air seperti 
ungkapan hadis di atas, karena pada hakekatnya ia tidak diketahui dan masih samar (tidak jelas).

Implikasi pelarangan gharar adalah dihapuskannya berbagai bentuk kegiatan yang mendorong spekulasi dan perjudian dalam berbagai aktivitas ekonomi. Gharar akan menciptakan instabilitas dan kerapuhan dalam perekonomian, baik dalam jangka pendek atau jangka panjang.

\section{Pelarangan yang Haram}

Prinsip dasar dalam Islam bahwa yang dilakukan harus halalan thayyiban (Q.s. al-Baqarah [2]: 168), yakni benar secara hukum Islam dan baik dari perspektif nilai dan moralitas Islam, kebalikannya adalah haram. Haram dalam hal ini terkait dengan zat prosesnya. Dalam zat Islam melarang mengkonsumsi, memproduksi, mendisttribusikan dan seluruh mata rantainya terhadap beberapa komoditas dan aktivitas yang dilarang (diharamkan) (Q.s. al-Maidah [5]: 3). Dalam hal proses Islam melarang (mengharamkan) setiap bentuk transaksi karena tiga hal (Pusat Pengkajian Ekonomi Islam UII, 72-73) yaitu: pertama, perbuatan atau transaksi yang mengandung unsur atau potensi ketidakadilan (Q.s. an-Nisa [4]: 29), seperti pencurian, riba, perjudian dan lain-lain. Kedua, transaksi yang melanggar prinsip saling ridha, seperti tadlis. Ketiga, perbuatan yang merusak harkat martabat manusia atau alam semesta, seperti prostitusi, minum khamar dan lain-lain.

\section{E. Distribusi Pendapatan dan Kekayaan dalam UUD 1945 \\ Dasar konstitusi kehidupan} ekonomi nasional Indonesia adalah UUD 1945. Secara spesifik doktrin kebangsaan dan doktrin kerakyatan terdapat pada pasal 33 UUD 1945, pasal 34 dan pasal 27. Pasal-pasal ini menjadi benteng nasionalisme ekonomi dan benteng pengutamaan kepentingan kehidupan seluruh rakyat Indonesia. Ini penting dibahas karena berbicara tentang ekonomi dalam konteks keindonesiaan.

Pasal 33 UUD 1945 berbunyi:

(1) Perekonomian disusun sebagai usaha bersama berdasar atas asas kekeluargaan; (2) Cabang-cabang produksi yang penting bagi Negara dan yang menguasai hajat hidup orang banyak dikuasai oleh Negara; (3) Bumi dan air dan kekayaan alam yang terkandung di dalamnya dikuasai oleh Negara. 
Implementasi Pasal 33 UUD 1945 menegaskan ketentuan-ketentuan imperatif bagi Negara untuk mengatur perekonomian. Ayat 1 menyatakan: "Perekonomian disusun sebagai usaha bersama berdasar atas asas kekeluargaan". "Perekonomian disusun", artinya tidak boleh dibiarkan tersusun sendiri oleh kekuatan-kekuatan dan kemauan pasar bebas (laissez-fraire) yang rakus, penuh persaingan yang mematikan serta membawa ketidakadilan dan menumbuhkan kesenjangan sosial. Pemerintahlah yang mempunyai otoritas mengaturnya. Karl Polanyi dalam bukunya The Great Transformation mengingatkan bahwa menyerahkan mekanisme pasar untuk menjadi pengendali tunggal nasib manusia dan lingkungan alami mereka akan mengakibatkan penghancuran masyarakat. Manusia akan musnah sebagai korban disalokasi sosial yang akut (Polanyi; 2001, 76).

Pasal lain yang menjamin keadilan distribusi pendapatan terdapat pada pasal 27 (ayat 2): "Tiap-tiap warga negara berhak akan pekerjaan dan penghidupan yang layak bagi kemanusiaan" dan pasal 34: "Fakir dan miskin dan anak-anak terlantar dipelihara oleh Negara". Pesan konstitusi tersebut ditafsirkan oleh Sri-Edi
Swasono, (Swasono; 2010, 88) bahwa tiap-tiap warga negara berhak akan pekerjaan, artinya anti pengangguran, dan penghidupan yang layak bagi kemanusiaan (anti kemiskinan) harus mengawali dan menjadi titik tolak strategis perencanaan pembangunan nasional. Tanpa pekerjaan orang miskin akan tetap miskin dan sengsara. Meskipun mereka memperoleh santunan Jaring Pengaman Sosial (JPS), Bantuan Langsung Tunai (BLT), bantuan pangan, pengobatan gratis dan sekolah gratis dan lain-lain tidak akan merubah keadaan mereka yang miskin secara signifikan. Mereka akan tetap miskin selama tidak bisa menyalurkan dan meningkatkan kapasitas produktifnya dalam proses pembangunan ekonomi. Cara terbaik dan efektif untuk mengatasi kemiskinan adalah dengan memberantas pengangguran dengan membuka lapangan pekerjaan, dengan cara ini merubah posisi orang miskin dan penganggur sebagai beban (social liability) menjadi penyumbang added-values pada GDP. Dengan demikian rakyat memperoleh nilai tambah sosial ekonomi dan sosiol-kultural, yakni memperoleh nilai tambah ekonomi dengan meningkatnya produktivitas rakyat dan mengangkat harkat martabat rakyat. 
Sementara pemahaman pasal 34 secara konsisten tidak boleh dipisahkan dari pasal 27 (ayat 2) yang memberikan hak sosial rakyat. Artinya pada pasal 34 UUD 1945 perkataan "dipelihara oleh Negara", memberi dimensi "pemberdayaan oleh Negara", anak terlantar tidak saja sekedar disantuni tetapi juga dimampukan dengan pendidikan dan pengasuhan sebagaimana dikehendaki pasal 27 (ayat 2).

\section{F. Kesimpulan}

\section{Distribusi} pendapatan merupakan proses peredaran/ penyaluran harta dari yang empunya kepada pihak yang berhak menerimanya baik melalui proses distribusi secara komersial maupun melalui proses yang menekankan pada aspek keadilan sosial. Tujuannya adalah; agar harta benarbenar terdistribusi dengan adil dan merata, (Q.s. al-Hasyr [59 ]: 7) dan untuk memenuhi kebutuhan hidup tiap individu muslim maupun untuk meningkatkan kesejahteraannya, human falah. Prinsip utama yang menentukan dalam distribusi kekayaan adalah keadilan (justice) dan kasih sayang (persaudaraan). Kebijakan-kebijakan Islam dalam mewujudkan keadilan dalam distribusi pendapatan dan kekayaan; adanya penghapusan riba, adanya kewajiban zakat, pengharaman yang haram dan pelarangan gharar. Sebab Sistem distribusi hanya dengan dua, yaitu yang bersifat komersial melalui mekanisme pasar dan sistem yang menekankan dimensi keadilan yang diperuntukkan bagi kalangan yang lemah. Sementara prinsip distribusi; pertama, prinsip pemenuhan kebutuhan bagi semua makhluk. Kedua, menimbulkan efek positif bagi pemberi itu sendiri. Ketiga, menciptakan kebaikan di antara semua orang antara yang kaya dan miskin. Keempat, mengurangi kesenjangan pendapatan dan kekayaan. Kelima, pemanfaatan lebih baik terhadap sumber daya alam dan aset tetap. Keenam, memberikan harapan pada orang lain melalui pemberian. Secara spesifik doktrin kebangsaan dan doktrin kerakyatan terdapat pada pasal 33 UUD 1945, pasal 34 dan pasal 27. Pasal-pasal ini menjadi benteng nasionalisme ekonomi dan benteng pengutamaan kepentingan kehidupan seluruh rakyat Indonesia termasuk dalam hal distribusi pendapatan dan kekayaan. 
DAFTAR PUSTAKA

Al-Ghaffar, Muhammad Abdul Mun'im. Al-Iqtishad al-Islami: al-Iqtishad alJuz'i, jilid 3. Irak: Dar al-Bayan, 1985.

Al-Qurtubi, Abu al-Walid Muhammad ibn Ahmad ibn Muhammad ibn Ahmad ibn Rusyd. Bidayah alMujtahid wa an-Nihayah al-Muqtasid. Beirut: Dar al-Ma'rifah, 1981, Juz 2.

Al-San'ani. Subul al-Salam, Edisi ke 4, Jilid 3. Beirut: Dar Ihya al-Turast al'Arabi, 1379 H. Edisi ke 4, Jilid 3.

Amalia, Euis. Keadilan Distribusi dalam Ekonomi Islam. Jakarta: Rajawali Pers, 2009.

Antonio, M. Syafi'i. "Konsep Distribusi Islam”, Republika, 5 April 2004.

Chapra, M. Umer. Masa Depan Ilmu Ekonomi: Sebuah Tinjauan Islam. Jakarta: Gema Insani Press, 2001.

Chapra, Muhammad Umer. "Monetary Management In An Islamic Economy", Islamic Economic Studies, Vol. 4, No. 1, (Desember 1996).

Hulwati. Ekonomi Islam. Jakarta: Ciputat Press, 2006.

Indriyo. Manajemen Keuangan. Yogyakarta: FE UGM, 1980.

Kahf, Mozer. Ekonomi Islam: Telaah Analitik terhadap Fungsi Sistem Ekonomi Islam, terj. Machnum Husein dari The Islamic Economy: Analitical of the Functioning of the Islamic Economy System. Yogyakarta: Pustaka Pelajar, 1995.

Muhammad. Ekonomi Mikro dalam Perspektif Islam. Yogyakarta: BPFE, 2005.
Nasution, Mustafa Edwin, dkk. Pengenalan Eklusif Ekonomi Islam. Jakarta: Kencana Prenada Media Group, 2007.

Polanyi, Karl. The Great Transformation. Boston: Beacon, 2001.

Al-Qazwayni, Muh. Ibn Yazid Abu Abdillah. Sunan Ibnu Majah (Beirut: Darul Fikr), Jilid 2.

Pusat Pengkajian dan Pengembangan Ekonomi Islam (P3EI) \& UII Yogyakarta. Ekonomi Islam. Jakarta: Rajawali Pers, 2008.

Rahman, Afzalur. Doktrin Ekonomi Islam, Jilid 1, terj. Drs. H.M. Sonhadji, dkk. Yogyakarta: Dana Bhakti Wakaf, 1995.

Sadeq, A.M. "Factor Pricing and Income Distribution from an Islamic Perspective" dalam Journal of Islamic Economics, 1989.

Sakti, Ali. Analisis Teoritis Ekonomi Islam: Jawaban Atas Kekacauan Ekonomi Modern. Jakarta: Paradigma \& Aqsa Publishing, 2007.

Shihab, M. Quraisy. Tafsir al-Misbah, Jilid 1. Jakarta: Lentera Hati, 2002.

Siddiqi, Muhammad Nejatullah. Banking Without Interest. Lahore: Islamic Publications Limited Shahalam Market, 1997.

Swasono, Sri-Edi. "Paradigma Baru Ilmu Ekonomi." Pidato Kunci pada Workshop Nasional Arsitektur Ilmu Ekonomi Islam: Upaya Akselerasi Sistem Ekonomi Islam di Indonesia. Jakarta: UIN Syarif Hidayatullah, 28 Februari 2012.

Swasono, Sri-Edi. "Ekonomi Islam dalam Pancasila", Makalah Interntional Seminar on Implementation of Islamic Economics, dalam rangka Annual Meetingf of Indonesian 
Economics Experts Association UNAIR. Surabaya, 1-3 Agustus 2008.

Swasono, Sri-Edi. Indonesia dan Doktrin Kesejahteraan Sosial. Jakarta: Perkumpulan Prakarsa, 2010.

Swasono, Sri-Edi. Kebersamaan dan Asas Kekeluargaan Mutualism \&
Broterhood. Jakarta: UNJ Press, 2005.

Thurow, Lester C. Creating Wealth: The New Rules For Individual, Companies and Countries in a Knowledge Based Economy. London: Nicholas Brealy, 